\title{
Simulated E ffects of R educed Sulfur, Nitrogen, and Base Cation Deposition on Soils and Solutions in Southern Appalachian Forests
}

\author{
D. W. Johnson,* R. B. Susfalk, P. F. Brewer, and W. T. Swank
}

\begin{abstract}
E ffects of reduced deposition of $N, S$, and $C_{B}$ on nutrient pools, fluxes, soil, and soil solution chemistry were simulated for two Appalachian forest ecosystems using the nutrient cycling model. In the extremely acidic, N- and S-saturated red spruce [Picea rubens (Sarg.)] forest (Nolan Divide), reducing $\boldsymbol{C}_{\mathrm{B}}$ deposition by $50 \%$ reduced $\boldsymbol{C}_{\mathrm{B}}$ leaching by $-40 \%$ during the $24-y r$ simulation period. This was due solely to the effects of $C_{B}$ deposition on the soil exchanger rather than effects on soil solution. R educing $S$ and $N$ by $\mathbf{5 0 \%}$ caused immediate reductions in total anion and cation leaching at Nolan Divide, but the effects on soil solution $C_{\mathrm{B}}$ diminished and $C_{\mathrm{B}}$ leaching was reduced by only $17 \%$ over the simulation period. R educing $\mathbf{S}$ and $\mathrm{N}$ deposition had a greater effect on soil solution aluminum (Al) and molar $\mathbf{C a} / \mathbf{A l}$ ratio than reducing base cation deposition at $\mathrm{N}$ olan $\mathrm{Divide}$. In the moderately acidic, $\mathrm{N}$ - and $\mathrm{S}$-accumulating mixed deciduous forest at Coweeta, reduced $\boldsymbol{C}_{\mathrm{B}}$ deposition by $50 \%$ caused a very slight $(<4 \%)$ reduction in $\boldsymbol{C}_{\mathrm{B}}$ leaching as a result of slightly reduced base saturation and increased soil sulfate adsorption. The effects on reducing $\mathbf{S}$ and $\mathrm{N}$ deposition by $50 \%$ on $C_{\mathrm{B}}$ leaching ( $16 \%$ over the simulation period) were greater than those of reduced $C_{\mathrm{B}}$ deposition. The system continued to accumulate both $\mathbf{S}$ and $\mathbf{N}$ even at reduced deposition at $\mathbf{C o -}$ weeta, although growth and vegetation uptake were slightly reduced $(-5 \%)$ because of increased $N$ deficiency. Base saturation remained well above the Al buffering range at all times at Coweeta and Al was an unimportant component of soil solutions in all scenarios.
\end{abstract}

S EVERAL researchers have suggested in recent years that changes in base cation $\left(C_{\mathrm{B}}\right)$ deposition may be an important factor in soil acidification, nutrition, and streamwater acidification. Hedin et al. (1994), for example, reported steep declines in precipitation $C_{B}$ inputs in both Europe and North America over a period of 10 to $26 \mathrm{yr}$. The authors assert that these declines in $\boldsymbol{C}_{\mathrm{B}}$ have offset concurrent declines in $S$ deposition, and may be contributing "to the increased sensitivity of poorly buffered ecosystems." Driscoll et al. (1989a, 1989b, $1989 \mathrm{c}$ ) noted a decline in both $\mathrm{SO}_{4}^{2-}$ and $C_{\mathrm{B}}$ in atmospheric deposition and streamwater over two decades at Hubbard Brook Watershed, New Hampshire. The authors presented two alternative hypotheses for the decline in streamwater $C_{\mathrm{B}}$ : (i) the decline in $C_{\mathrm{B}}$ deposition or (ii) the necessary decline in total cations due to the decline in streamwater $\mathrm{SO}_{4}^{2-}$ concentration. Based on regression analyses, Driscoll et al. (1989c) appeared

D.W. Johnson, Desert Research Inst., 2215 Raggio Parkway, Reno, NV 89512; R.B. Susfalk, Environmental and Resource Sciences, Univ. of Nevada, Reno, NV 89512; P.F. Brewer, Tennessee Valley Authority, Chattanooga, TN 37402; and W.T. Swank, U.S. Forest Service, Coweeta Hydrologic Lab., Otto, NC 28763. Received 22 June 1998. *Corresponding author (dwj@dri.edu).

Published in J. Environ. Qual. 28:1336-1346 (1999). to favor the first hypothesis, sparking a heated discussion (Holdren and Church, 1989; Driscoll et al., 1989b, 1989 c). One of the focal points of the controversy was whether soil exchangeable $C_{\mathrm{B}}$ pools could have changed sufficiently over two decades to cause the observed decline in streamwater $C_{\mathrm{B}}$. Likens et al. (1996) suggested that soil exchangeable $C_{\mathrm{B}}$ pools have declined at Hubbard Brook, citing evidence from streamwater trends and reductions in 0 horizon $C_{\mathrm{B}}$ concentrations with time. Changes in mineral soil exchangeable $C_{\mathrm{B}}$ cation pools over decadal time periods have been documented in soils in the northeastern USA (Johnson and Anderson, 1994) and in other parts of the world (Binkley et al., 1989; Falkengren-Grerup et al., 1987; Johnson et al., 1988).

In this article, we explore the effects of reduced $\mathrm{N}$, $\mathrm{S}$, and $C_{\mathrm{B}}$ deposition on two contrasting forest ecosystems in the southern Appalachians. The Nutrient Cycling Model (NuCM) was used to simulate the responses of an extremely acidic red spruce (Picea rubens Sarg.) site in the Great Smoky Mountains of North Carolina (Nolan Divide) and a moderately acidic mixed deciduous site in the Appalachian mountains of North Carolina (Coweeta) to reduced $\mathrm{N}, \mathrm{S}$, and $C_{\mathrm{B}}$ deposition. The primary purpose of this exercise was to examine the mechanisms by which these systems respond to reduced $\mathrm{N}, \mathrm{S}$, and $C_{\mathrm{B}}$ deposition rather than to produce predictions.

\section{SITES AND METHODS}

\section{The Nutrient Cycling Model}

Nutrient cycling model is a stand-level nutrient cycling model developed as part of the Integrated Forest Study (Liu et al., 1991; Johnson and Lindberg, 1991; Johnson et al., 1993). The forested ecosystem is represented as a series of vegetation and soil components. The model provides for both an overstory and understory, each of which can be divided into canopy, bole, and roots. Tree growth in the model is a function of user-defined stand developmental stage and the availability of nutrients and moisture. Translocation of nutrients before senescence is included and is also user-defined. Using mass balance and transport formulations, the model tracks 16 solution-phase components including the major cations and anions (analytical totals), ANC (acid-neutralizing capacity), an or-

Abbreviations $50 \% \mathrm{~S}, \mathrm{~N}=$ a scenario reducing sulfur and nitrogen deposition by $50 \% ; 50 \% C_{\mathrm{B}}=$ a scenario reducing base cation deposition by $50 \% ; 50 \% \mathrm{~S}, \mathrm{~N}, C_{\mathrm{B}}=$ a scenario reducing sulfur, nitrogen, and base cation deposition by $50 \% ; C_{\mathrm{B}}=$ base cations, $\mathrm{Ca}^{2+}+\mathbf{M g}^{2+}+$ $\mathrm{K}^{+}+\mathrm{Na}^{+}$; No Change (NC) $=$a scenario with deposition at 1985-1989 levels; $\mathbf{N u C M}=$ Nutrient Cycling Model; $\mathbf{M A A}=$ mineral acid anions in soil solution. 


\section{NolanDivide}
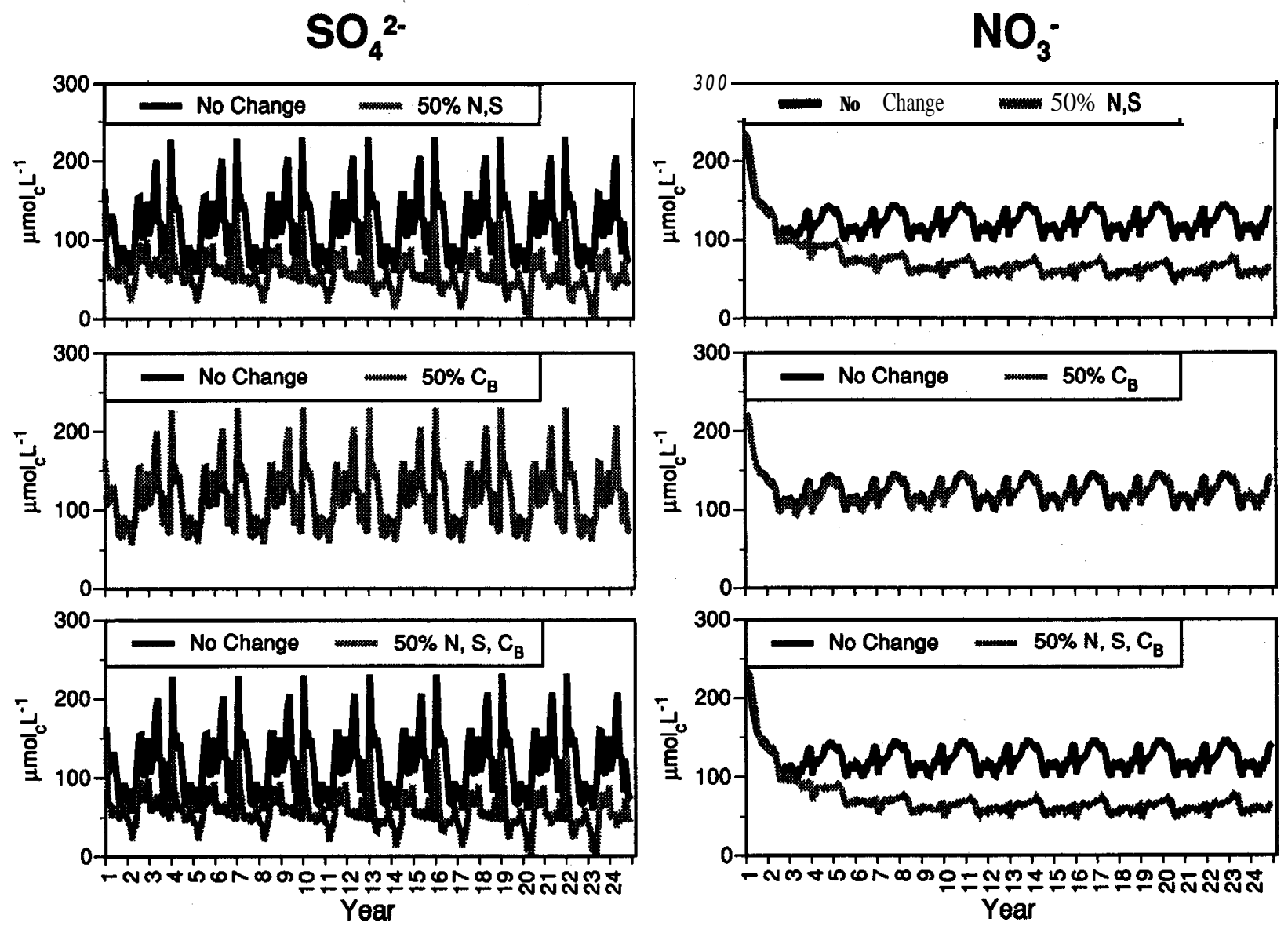

Fig. 1. Simulated soil solution $\mathrm{SO}_{4}^{2-}$ (left) and $\mathrm{NO}_{3}^{-}$(right) in the Bw3 horizon at Nolan Divide. (No Change $=$a scenario witb deposition at 19854989 levels; $50 \% \mathrm{~N}, \mathrm{~S}=$ a scenario reducing $\mathrm{N}$ and $\mathrm{S}$ deposition by $\mathbf{5 0 \% ;} \mathbf{5 0 \%} \boldsymbol{C}_{\mathrm{B}}=$ a scenario reducing base cation deposition by $\mathbf{5 0 \%}$; $50 \% \mathrm{~S}, \mathrm{~N}, \boldsymbol{C}_{\mathrm{B}}=$ a scenario reducing $\mathrm{N}, \mathrm{S}$, and base cotton deposition by $50 \%$ ).

ganic acid analogue, and total $\mathrm{Al}$ (Liu et al., 1991). The concentrations of $\mathrm{H}^{+}, \mathrm{Al}$ and $\mathrm{CO}$, species, and organic acid ligands and complexes are then calculated based on the 16 components. The acid-base characteristics of the forest soil solution are computed by the model to properly account for the influence of $\mathbf{H}^{+}$concentration on cation exchange and mineral weathering.

The model routes precipitation through the canopy and soil layers, and simulates evapotranspiration, deep seepage, and lateral flow. The soil includes multiple layers (up to 10), and each layer can have different physical and chemical characteristics. The movement of water through the system is simulated using the continuity equation, Darcy's equation for permeable media flow, and Manning's equation for free surface flow. Percolation occurs between layers as a function of layer permeabilities and differences in moisture content.

Nutrient pools associated with soil solution, the ion exchange complex, minerals, and soil organic matter are all tracked explicitly. The processes that govern interactions among these pools include organic matter decay, nitrification, anion adsorption, cation exchange, and mineral weathering. Mineral weathering reactions are described in the model using rate expressions with dependencies on the mass of mineral present and solution-phase $\mathbf{H}^{+}$concentration taken to a fractional power. Cation exchange is represented by the Gapon equation:

$$
\frac{\left[E C^{\mathrm{a}+}\right]\left(C^{\mathrm{b}+}\right)^{1 / \mathrm{b}}}{\left[E C^{\mathrm{b}+}\right]\left(C^{\mathrm{a}}\right)^{1 / \mathrm{a}}}=\mathrm{Kgp}
$$

where $\boldsymbol{E}=$ exchange phase equivalent fraction, ()$=$ soil solution activity, $C^{\mathrm{a}+}=$ cation of valence $\mathrm{a}, \boldsymbol{C}^{\mathrm{b}+}=$ cation of valence $\mathrm{b}$, and $\mathrm{Kgp}=$ selectivity coefficient. Aluminum solubility is simulated in the model according to one of three options: Option 1 = no solution reaction with respect to gibbsite $\left[\mathrm{Al}(\mathrm{OH})_{3}\right]$, Option $2=$ equilibrium with respect to gibbsite, or Option $3=$ a rate limited approach to equilibrium with gibbsite. In organic-rich surface horizons, Option 3 is recommended because solutions are often out of equilibrium with gibbsite (Munson et al., 1992). In lower horizons, either Option 2 or 3 are recommended; Option 2 was used in these simulations.

The model simulates the noncompetitive adsorption of sulfate, phosphate, and organic acid. Phosphate adsorption in the model is represented by a linear isotherm. Sulfate adsorption can be simulated using either linear or Langmuir adsorption isotherms; the Langmuir isotherm was used in these simulations. Unlike most models of its kind (Prenzel, 1994), NuCM simulates pH-dependent $\mathrm{SO}_{4}^{2-}$ adsorption according to the following reaction:

$$
X s+2\left(\mathrm{H}^{+}\right)+\mathrm{SO}_{4}^{2-} \stackrel{k}{\rightarrow} X_{\mathrm{H} 2 \mathrm{SO} 4}
$$




$$
k=\frac{X_{\mathrm{H} 2 \mathrm{SO} 4}}{(X s)\left(\mathrm{H}^{+}\right)^{2}\left(\mathrm{SO}_{4}^{2-}\right)}
$$

where $X_{\mathrm{H} 2 \mathrm{SO} 4}=$ the number of sites onto which $\mathrm{SO}_{4}^{2-}$ is adsorbed and $\mathrm{Xs}=$ unfilled adsorption sites. Expressed in the Langmuir formulation:

$$
\mathbf{X}_{\mathrm{H} 2 \mathrm{SO} 4}=\frac{\left(X_{\max }\right)(b)\left(\mathrm{SO}_{4}^{2-}\right)}{\mathbf{1}+(b)\left(\mathrm{SO}_{4}^{2-}\right)}
$$

where $\boldsymbol{X}_{\max }=$ maximum sulfate that can be adsorbed on soil, which equals $X_{\mathrm{H} 2 \mathrm{SO} 4}+\mathrm{Xs}$ from Eq. [2] and $b=k\left(\mathrm{H}^{+}\right)^{2}$ from Eq. [2].

Model input is based on measurable parameters and is accomplished using a series of menus or automatic transfer of data from previously entered files. The model uses such data to compute selectivity coefficients for each soil layer simulated. Further details on the structure of NuCM are given by Liu et al. (1991) and Johnson et al. (1993).

\section{Sites}

\section{Nolan Divide}

The Nolan Divide site is located at an elevation of approximately $1740 \mathrm{~m}$ on a southerly slope $\left(15^{\circ}\right)$ on Nolan Divide near Clingman's Dome in the Great Smoky Mountains National Park on the Tennessee-North Carolina border. The climate of the area is characterized by cool summers and cold but not severe winters. Mean annual temperature is $6{ }^{\circ} \mathrm{C}$ and mean annual precipitation is $203 \mathrm{~cm}$. Soils are Umbric Dystrochrepts derived from Thunderhead sandstone. The overstory vegetation is dominated by old-growth red spruce with occasional Fraser fir [Abies fraseri (Pursh.) Poir], many of which are suffering from infestations of the balsam wooly adelgid (Adelgespicea Ratzberg), and occasional yellow-birch (Betula alleghaniensis Britt.). Understory consists of patches of Fraser fir and occasional red spruce, blueberry (Vaccinium erythrocarpum Michx.), blackberry (Rubus canadensis L.), witch hobble (Viburnum alnifolium Marsh.), sorbus (Sorbus americana (Marsh.) DC), oxalis (Oxalis acetosella L.), and various ferns and mosses.

The Nolan Divide site is representative of soil chemistry and vegetation composition of spruce-fir stands in the southern Appalachians (Joslin et al., 1992): it is characterized by high rainfall and high atmospheric deposition rates; old, slow-growing spruce-fir vegetation; relatively shallow, extremely acidic, and N-rich soils (Johnson et al., 1991). These ecosystems show no net accumulation of either $\mathrm{S}$ or $\mathrm{N}$, biological demands for both nutrients are fully satisfied, and soil $\mathbf{S O}_{4}^{2-}$ adsorption capacity is very low (Johnson et al., 1991).

\section{Coweeta}

Coweeta is located at approximately $720 \mathrm{~m}$ elevation near Otto, NC. Mean annual temperature is $12.5^{\circ} \mathrm{C}$ and mean an-

\section{Nolan Divide}

\section{Mineral Acid Anions}
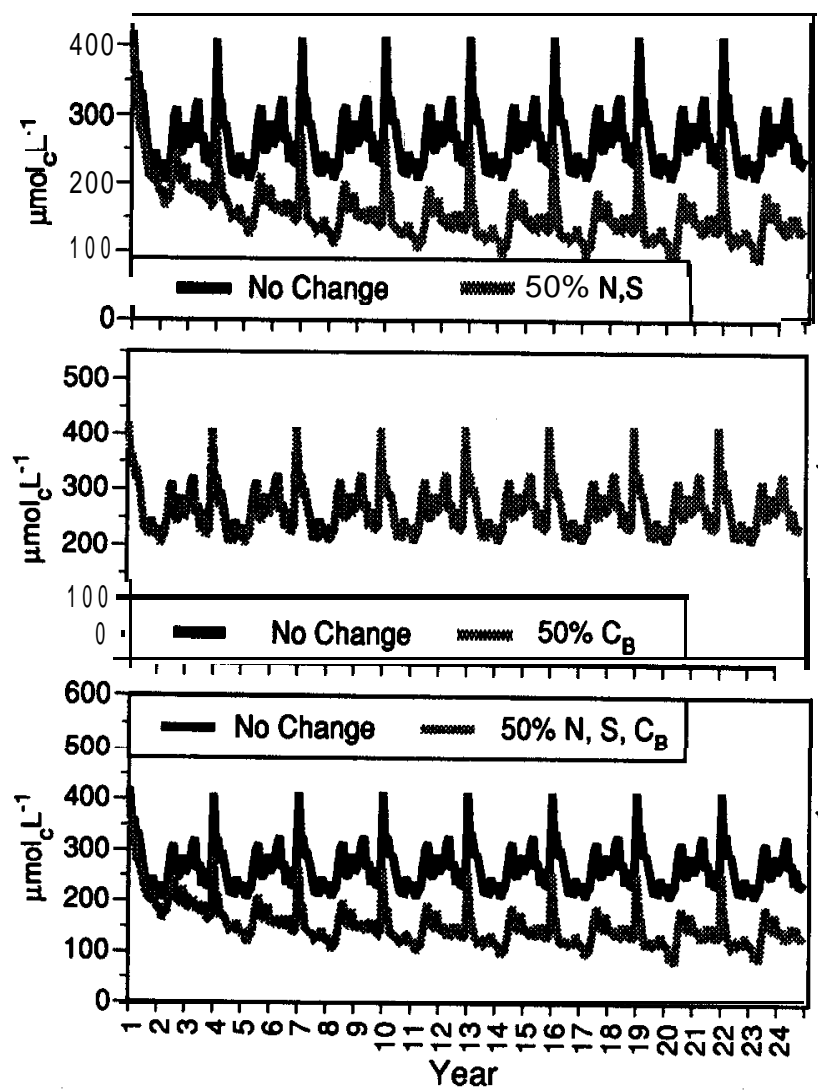

Fig. 2. Simulated soil solution mineral acid anion (left) and base cation for key).
Base Cations
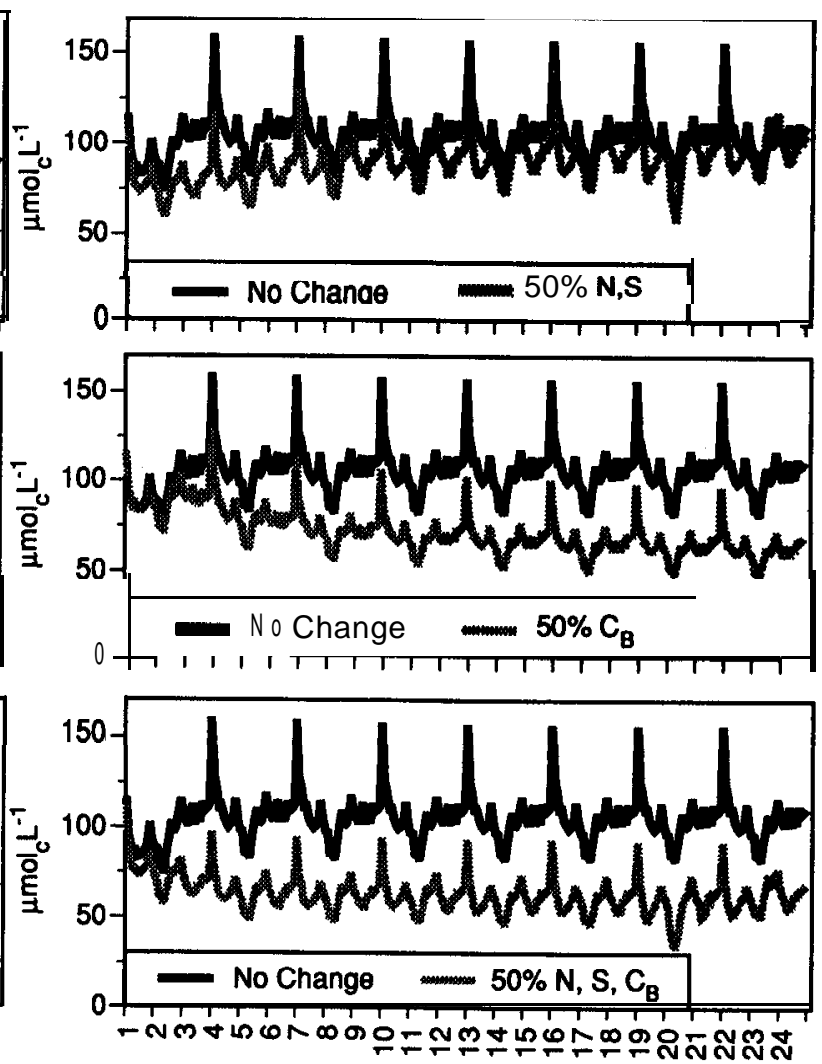

(right) concentrations in the Bw3 horizon at Nolan Divide (see Fig, 1 
nual precipitation is $138 \mathrm{~cm}$. Vegetation consists of native, mixed mesophytic hardwood forest typical of the region. The site has served as a control watershed since 1934, and no human-caused disturbance has occurred there since 1923. The multistoried, uneven-aged stand is composed of oak

spp.) (50\% of basal area), sourwood [0 xydendrum arboreum (L.) DC.] (11\%), great rhododendron (Rhododendron maximum L.) (11\%), red maple (Acer rubrum L.) (10\%), hickory (Carya spp.) (6\%), flowering dogwood (Cornus florida L.) $(3 \%)$, and other species (9\%). Soils (Fannin series) are mesic Typic Hapludults derived from gneiss and shist.

The Coweeta site is representative of southern Appalachian mixed deciduous forests: it is characterized by aggrading mixed deciduous forest vegetation and moderately acidic, low-N soils that have a high $\mathbf{S O}_{4}^{2-}$ adsorption capacity (Swank and Waide, 1988; Johnson et al., 1993). The Coweeta system strongly retains both $\mathrm{S}$ and $\mathrm{N}$ from atmospheric deposition (Swank and Waide 1988; Johnson and Lindberg, 1991).

\section{Simulation M ethods}

The NuCM Model has been previously calibrated and tested against field data for both the Nolan Divide and Coweeta sites (Johnson et al., 1993, 1996). Where field data were available for comparison, the model performed adequately for both sites: it simulated the essential features (but not the fine temporal detail) of solution chemistry at the Nolan Divide site (Johnson et al., 1996) and the long-term increases (but not the exact rate of increase) in $\mathrm{SO}_{4}^{2-}$ at Coweeta (Johnson et al., 1993). As in all modeling exercises, there were many cases where field data were not available for comparison with model output.

For these simulations, the meteorological and atmospheric deposition record at the Nolan site during the period 1 Jan. 1986 to 31 Dec. 1988 was repeated eight times to simulate deposition during a 24-yr period (Johnson et al., 1996). At Coweeta, meteorological data from the period 1 Jan. 1959 to 31 Dec. 1959 were repeated 24 times. Sulfur and N deposition levels measured in the field during 1986 through 1988 (Johnson and Lindberg, 1991) were used as a baseline (No Change scenario). The scenarios chosen for these simulations included No Change, $50 \% \mathrm{~N}$ and $\mathrm{S}$ deposition, $50 \% C_{\mathrm{B}}$ deposition, and $50 \% \mathrm{~N}, \mathrm{~S}$, and $C_{\mathrm{B}}$ deposition $\left(50 \% \mathrm{~N}, \mathrm{~S}, C_{\mathrm{B}}\right)$. National Atmospheric Deposition Program data indicate that between 1980 and $1992, \mathbf{S O}_{4}^{2-}, \mathrm{Ca}^{2+}$, and $\mathbf{M g}^{2+}$ deposition at Elkmont in the Great Smoky Mountains National Park decreased (23, 52 , and $64 \%$, respectively) while trends for other ions were not significant. At Coweeta, $\mathrm{SO}_{4}^{2-}, \mathrm{NO} ; \mathrm{Ca}^{2+}$, and $\mathrm{Mg}^{2+} \mathrm{de}-$ creased $36,25,56$, and $49 \%$, respectively, during the same period. Similar trends have been observed throughout the eastern USA (Lynch et al., 1995). Although N deposition did not decline at the Elkmont site, $\mathrm{N}$ was included in the Nolan Divide simulations, not only for the sake of consistency but also NO; is a major anion in soil solutions at this site (Johnson et al., 1991).

\section{Nolan Divide}

Al
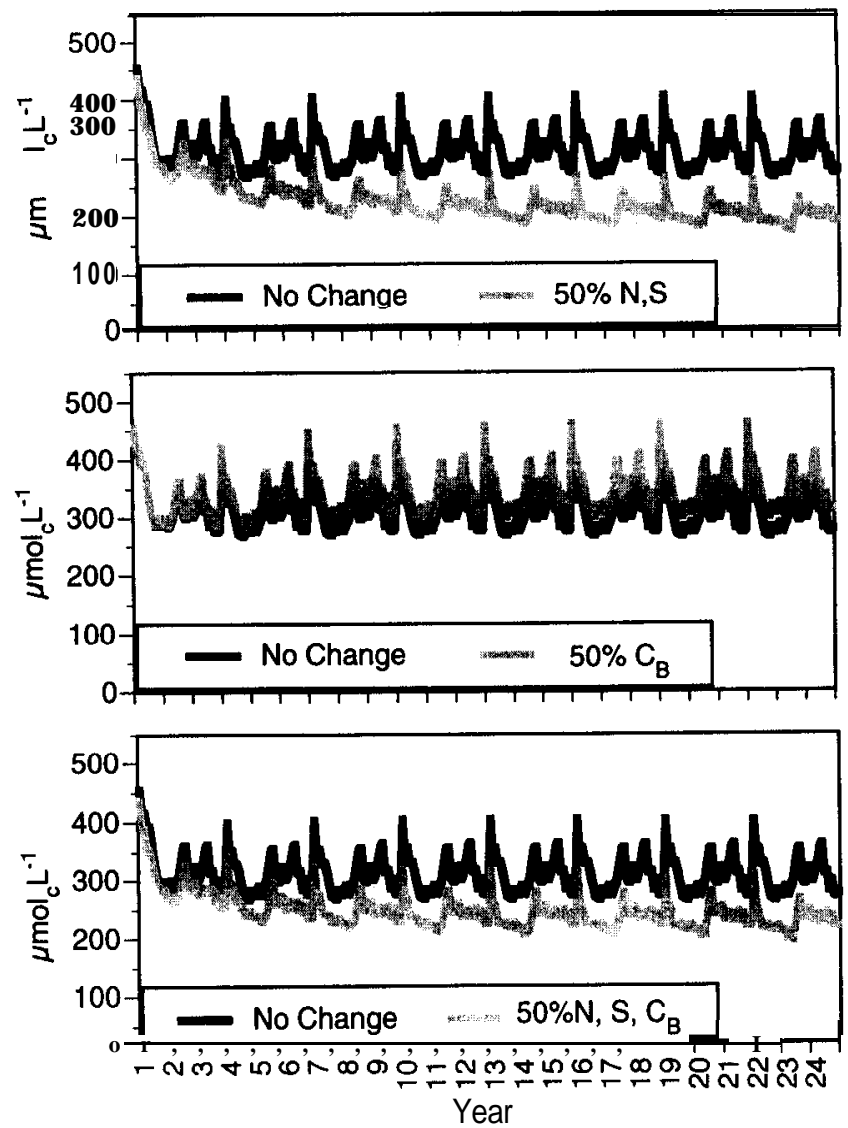

Molar Ca/Al Ratio
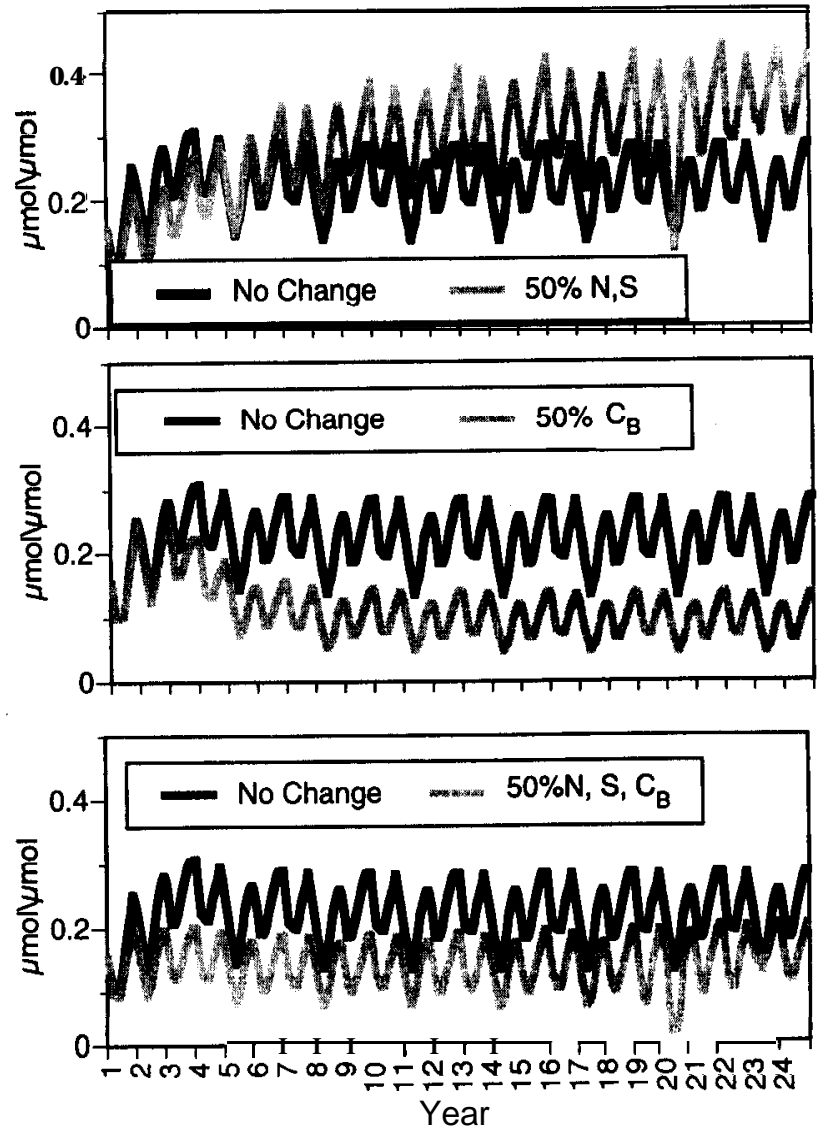

Fig. 3. Simulated soil solution $\mathbf{A l}^{3+}$ (left) and molar $\mathbf{C a} / \mathbf{A l}$ ratio (right) in the $\mathbf{B w 3}$ horizon at $\mathrm{N}$ olan Divide (see $\mathrm{Fig.} 1$ for key). 


\section{Nolan Divide}
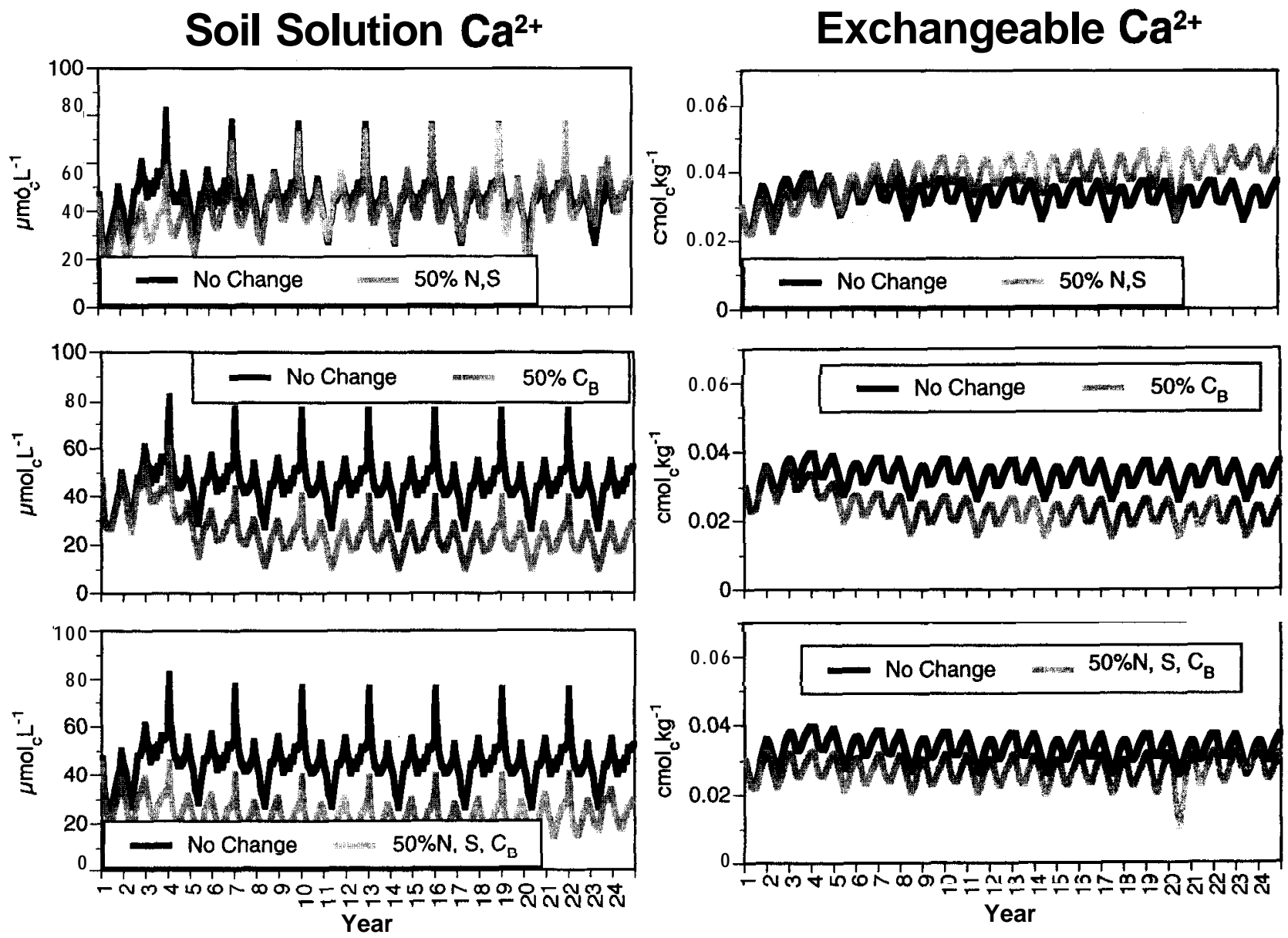

Fig. 4. Simulated soil solution $\mathrm{Ca}^{2+}$ (left) and exchangeable $\mathrm{Ca}^{2+}$ (right) in the $\mathrm{Bw3}$ horizon at $\mathrm{N}$ olan Divide (see Fig. 1 for key).

Changing $\mathrm{N}, \mathrm{S}$, and $C_{\mathrm{B}}$ resulted in changes in $\mathrm{H}^{+}$deposition in the model. The $50 \% \mathrm{~N}, \mathrm{~S}$ scenario had the effect of reducing $\mathbf{H}^{+}$deposition by an equivalent amount (because $\boldsymbol{C}_{\mathrm{B}}$ deposition was not changed), whereas the $50 \% \quad C_{\mathrm{B}}$ scenario had the effect of increasing $\mathrm{H}^{+}$deposition by an equivalent amount (because $\mathrm{S}$ and $\mathrm{N}$ deposition were not changed). Current model constraints limit the feasibility of changing the rate of deposition throughout the course of a simulation. Therefore, all scenarios were based on the simplified assumption that reductions begin in the first year of the simulation and remain constant during the entire $24-y$ r period.

\section{RESULTS}

\section{Effects on Simulated Soil and Soil Solution Concentrations}

\section{Nolan Divide}

The effects of the various scenarios on simulated soil and soil solution concentrations were extremely complex and a full discussion of all the interactions among treatments and horizons is beyond the scope of this paper. The following discussion summarizes the results from the deepest horizon soil solutions ( $\mathrm{Bw} 3$ at Nolan and $\mathrm{BC}$ at Coweeta).

Reductions in $\mathrm{N}$ and $\mathbf{S}$ deposition at Nolan Divide (both the $50 \% \mathrm{~N}, \mathrm{~S}$ and $50 \% \mathrm{~N}, \mathrm{~S}, C_{\mathrm{B}}$ scenarios) caused reductions in soil solution $\mathrm{NO} ; \mathrm{SO}_{4}^{2-}, \mathrm{MAA}, C_{\mathrm{B}}$, and $\mathrm{Al}$ concentrations compared with the No Change scenario within the first 3 to $5 \mathrm{yr}$ (Fig. 1-3). The relatively rapid response of soil solution $\mathrm{SO}_{4}^{2-}$ to reduced $\mathrm{S}$ deposition reflected the low buffering by soil $\mathrm{SO}_{4}^{2-}$ adsorption at this site. The rapid response of soil solution NO; to reduced $\mathrm{N}$ deposition reflected the fact that $\mathrm{N}$ deposition exceeded biological uptake and that $\mathrm{NO}_{3}^{-}$was a major component of soil solution before the reduction in deposition. The $50 \% C_{\mathrm{B}}$ scenario had virtually no effect on soil solution $\mathrm{SO}_{4}^{2-}$, NO; , and MAA concentrations at Nolan Divide, and the $50 \% \quad \mathrm{~N}, \mathrm{~S}, C_{\mathrm{B}}$ scenario caused a response in MAA concentrations, which was nearly identical to that in the $50 \% \mathrm{~N}, \mathrm{~S}$ scenario (Fig. 1 and 2).

Soil solution Al concentrations followed the same general patterns as MAA concentrations. In the 50\% $\mathrm{N}$, S scenario, soil solution Al decreased over the first $10 \mathrm{yr}$ and then stabilized, as did MAA concentrations (Fig. 2 and 3). Soil solution molar $\mathrm{Ca} / \mathrm{Al}$ ratio at first decreased slightly and then increased in response to reduced $\mathrm{Al}$ concentrations in the $50 \% \mathrm{~N}, \mathrm{~S}$ scenario. Molar $\mathrm{Ca} / \mathrm{Al}$ ratios never rose above the general toxicity threshold of 1.0 identified by Cronan and Grigal (1995), 


\section{Base Saturation - Nolan Divide}

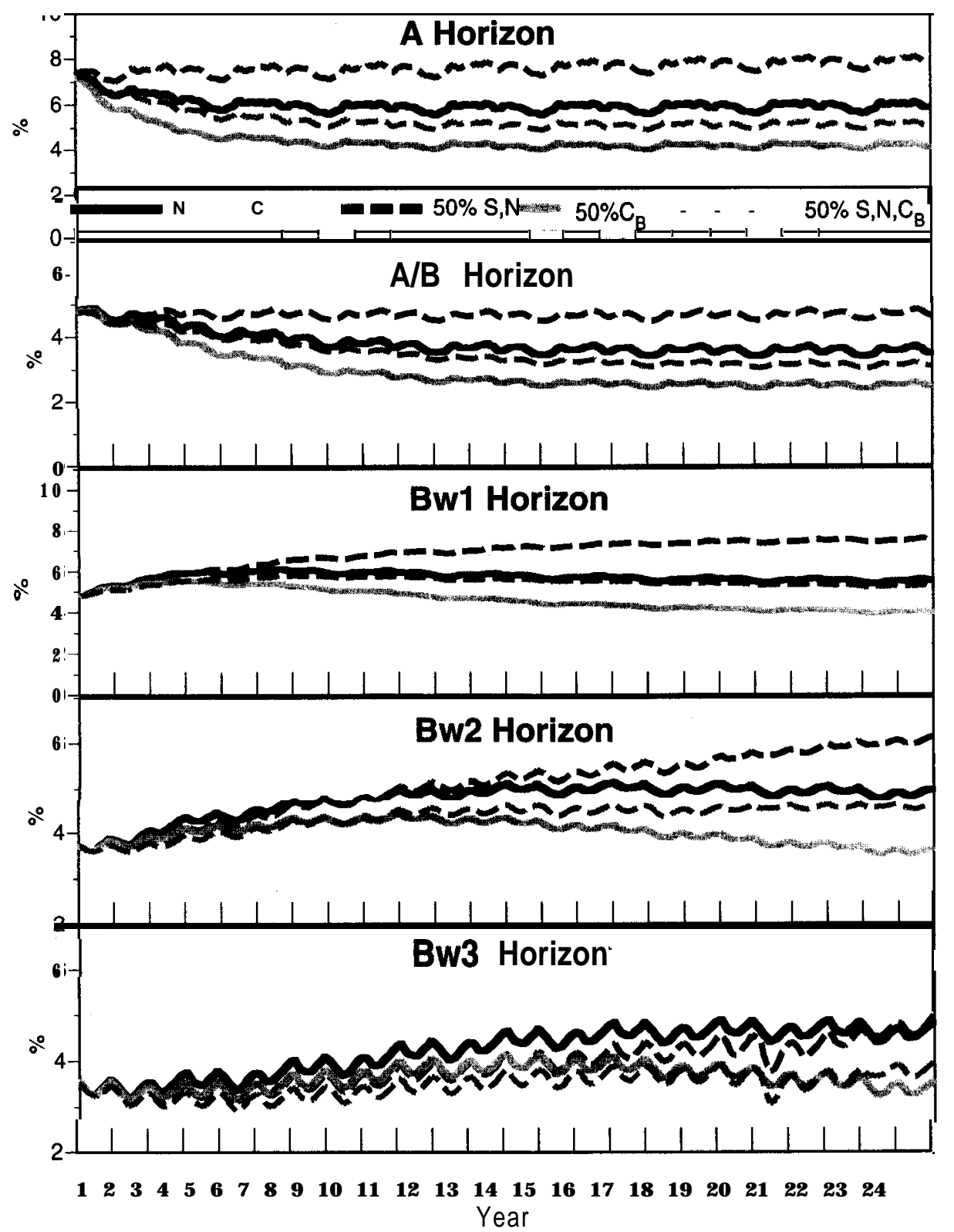

Fig. 5. Simulated base saturation at Nolan Divide (see Fig. 1 for key).

however. In the $50 \% C_{\mathrm{B}}$ scenario, the patterns in soil solution Al differed slightly from those in MAA concentrations: $\mathrm{Al}$ in increased very slightly relative to the No Change scenario, whereas MAA concentrations remained identical at all times (Fig. 2 and 3). The slight increases in soil solution $\mathrm{Al}$ was associated with a decrease in Bw3 horizon base saturation in the $50 \% C_{\mathrm{B}}$ scenario, and the reduction in soil solution molar $\mathrm{Ca} /$ $\mathrm{Al}$ ratio was a response to reduced base saturation and reduced soil solution $\mathrm{Ca}^{2+}$ concentrations (Fig. 3-5). Soil solution $\mathrm{Al}$ and $\mathrm{Ca} / \mathrm{Al}$ ratios in the $50 \% \mathrm{~N}, \mathrm{~S}, C_{\mathrm{B}}$ scenario followed patterns similar to but less pronounced than those in the $50 \% C_{\mathrm{B}}$ scenario (Fig. 3).

Soil solution $C_{\mathrm{B}}$ and $\mathrm{Ca}^{2+}$ concentrations followed patterns quite different from those in $\mathrm{Al}$ and MAA concentrations and more similar to those in base saturation and exchangeable $\mathrm{Ca}^{2+}$. The $50 \% \mathrm{~N}, \mathrm{~S}$ scenario caused immediate reductions in $C_{\mathrm{B}}$ and $\mathrm{Ca}^{2+}$ concentrations compared with the No Change scenario, but the differences diminished over time (Fig. 2). The patterns in solution $\mathrm{Ca}^{2+}$ generally followed those in exchangeable $\mathrm{Ca}^{2+}$ in the $50 \%$ N, S scenario (Fig. 4). The 50\% $C_{\mathrm{B}}$ scenario caused only minor reductions in $C_{\mathrm{B}}$ and $\mathrm{Ca}^{2+}$ concentrations initially, but the differences increased with time (Fig. 2 and 4). These patterns were similar to those in base saturation and exchangeable $\mathrm{Ca}^{2+}$ in the $50 \% C_{\mathrm{B}}$ scenario (Fig. 2 and 4). The $50 \%$ $\mathrm{N}, \mathrm{S}, C_{\mathrm{B}}$ scenario produced $C_{\mathrm{B}}$ and $\mathrm{Ca}^{2+}$ patterns similar 


\section{Coweeta}

Mineral Acid Anions

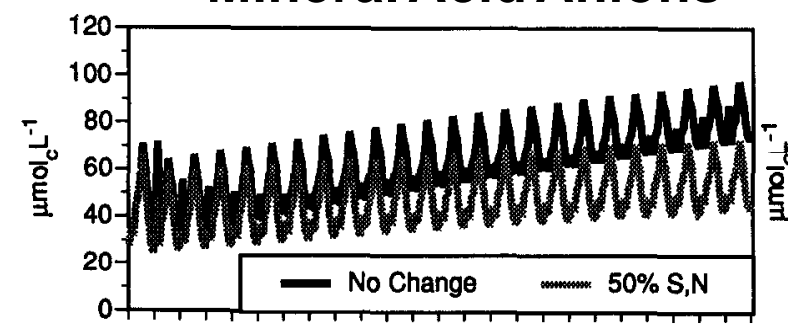

Base Cations
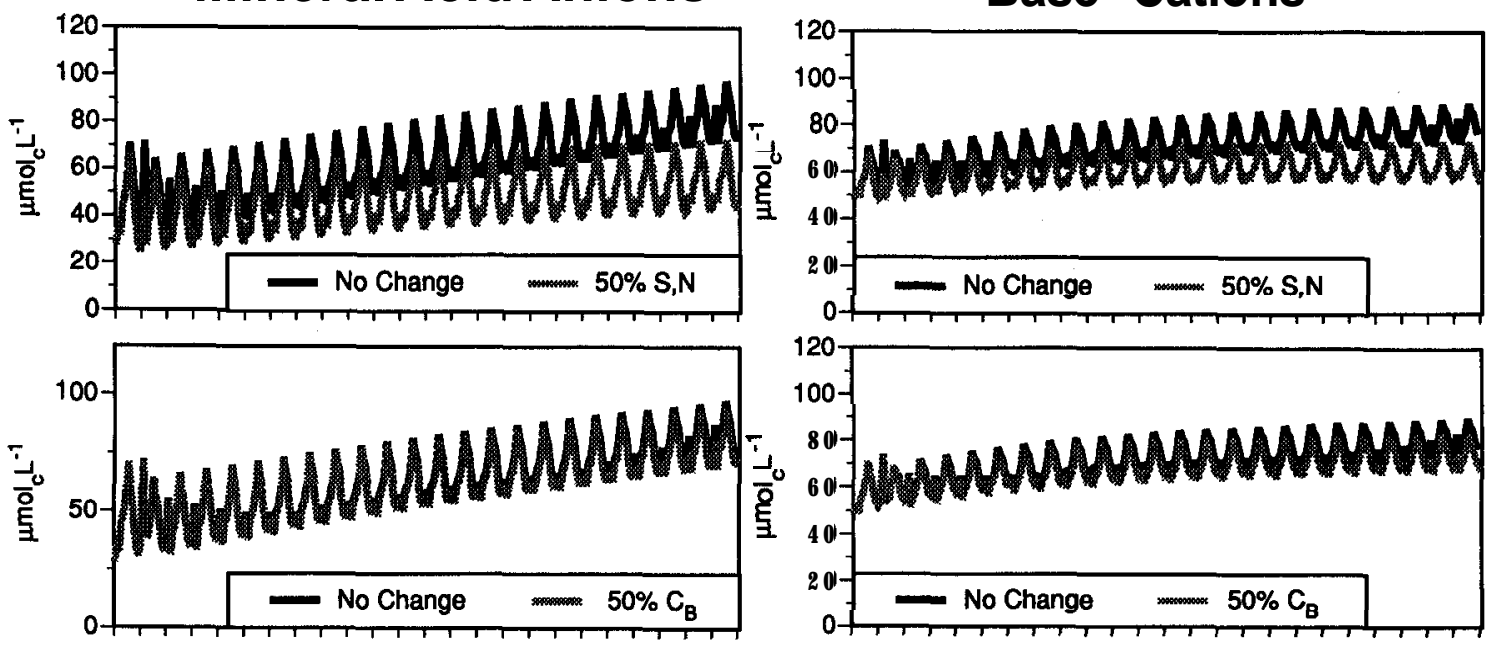
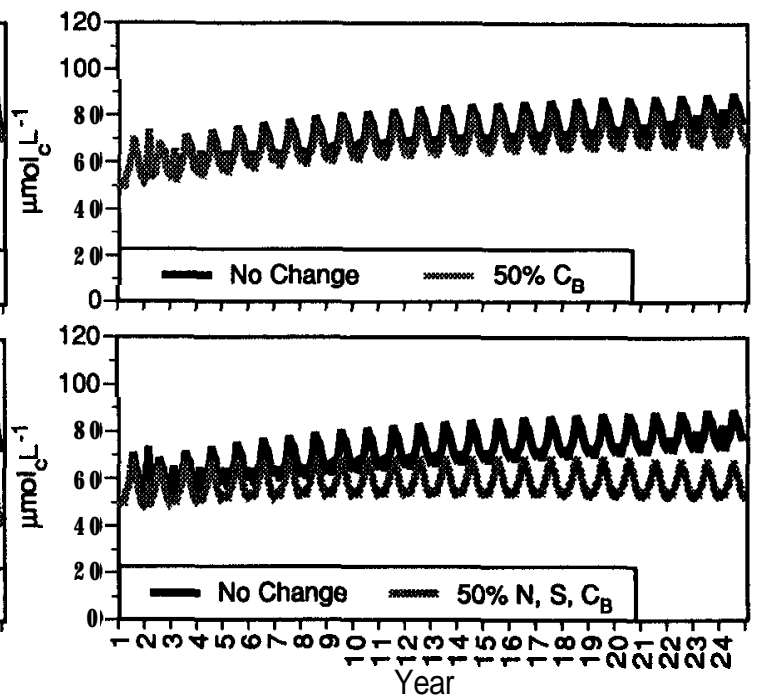

Fig. 6. Simulated soil solution mineral acid anion (left) and base cation

(right) concentrations in the BC horizon at Coweeta (see Fig. 1 for key).

to but less pronounced than those in the $50 \% C_{\mathrm{B}}$ scenario (Fig. 2 and 4).

The slight decrease in Bw3 horizon base saturation in the $50 \% \mathrm{~N}, \mathrm{~S}$ scenario is counterintuitive and merits closer examination. The $50 \% \mathrm{~N}, \mathrm{~S}$ scenario had the expected result of causing increased base saturation in the $\mathrm{A}$ and $\mathrm{A} / \mathrm{B}$ horizons relative to the No Change scenario throughout the simulation (Fig. 5). The reduction in base saturation in the $\mathrm{Bw}$ horizons was due to reduced leaching of base cations from the upper horizons. Thus, the $50 \% \mathrm{~N}, \mathrm{~S}$, scenario caused slightly reduced base saturation during Years 5 to 10 in the $\mathrm{Bwl}$ and $\mathrm{Bw} 2$ horizons and during most of the simulation in the Bw3 horizon. In contrast, the $50 \% \quad C_{\mathrm{B}}$ scenario caused uniform reductions in base saturation throughout the profile at all times during the simulation.

\section{Coweeta}

At the Coweeta site, MAA concentrations increased throughout the entire $24 \mathrm{yr}$ in all scenarios (Fig. 6). This was due to continuous increases in $\mathrm{SO}_{4}^{2-}$ concentration, reflecting the fact that the system was accumulating $\mathrm{S}$ as soil adsorbed $\mathrm{SO}_{4}^{2-}$, even with reduced $\mathrm{S}$ deposition (Fig. 7).

In contrast to Nolan Divide, there was a considerable delay in the response of MAA concentrations to the
$50 \%$ N, S scenario at Coweeta (Fig. 6). This was due to a delayed response in $\mathrm{SO}_{4}^{2-}$ concentrations because of greater buffering by soil $\mathbf{S O}_{4}^{2-}$ adsorption. The differences in $C_{\mathrm{B}}$ concentrations between the $50 \% \mathrm{~N}, \mathrm{~S}$ and No Change scenarios increased over time, corresponding to the pattern in MAA concentrations (Fig. 6 and 7). There were initially no differences in $\mathrm{SO}_{4}^{2-}$ or MAA concentrations between the $50 \% C_{\mathrm{B}}$ and No Change scenarios, but both decreased slightly relative to the No Change scenario in later years because of slight decreases in base saturation and concurrent increases in pH-dependent $\mathrm{SO}_{4}^{2-}$ adsorption (Fig. 8). Base cation concentrations followed the same pattern as MAA concentrations in the $50 \% C_{\mathrm{B}}$ and No Change scenarios (Fig. 6). Aluminum was an unimportant component of soil solutions at Coweeta (always $<1 \mu \mathrm{mol}_{\mathrm{c}} \mathrm{L}^{-1}$ ), and $\mathrm{Ca} / \mathrm{Al}$ ratios remained at least an order of magnitude above the nominal toxicity threshold of 1 .

As was the case at Nolan Divide, there was a reversal of base saturation effects in the deepest (BC) horizon in the $50 \% \mathrm{~N}, \mathrm{~S}$ scenario at Coweeta (Fig. 8). In the A and BA horizons, the expected increases in base saturation in the $50 \% \mathrm{~N}, \mathrm{~S}$ scenario occurred, but, because of reduced $C_{\mathrm{B}}$ leaching form upper horizons, the reverse occurred in the BC horizon (Fig. 8). Also as was the case at Nolan Divide, there was a uniform (but small) reduction in base saturation in all horizons in the $50 \%$ $C_{\mathrm{B}}$ scenario. 


\section{Base Saturation - Coweeta}

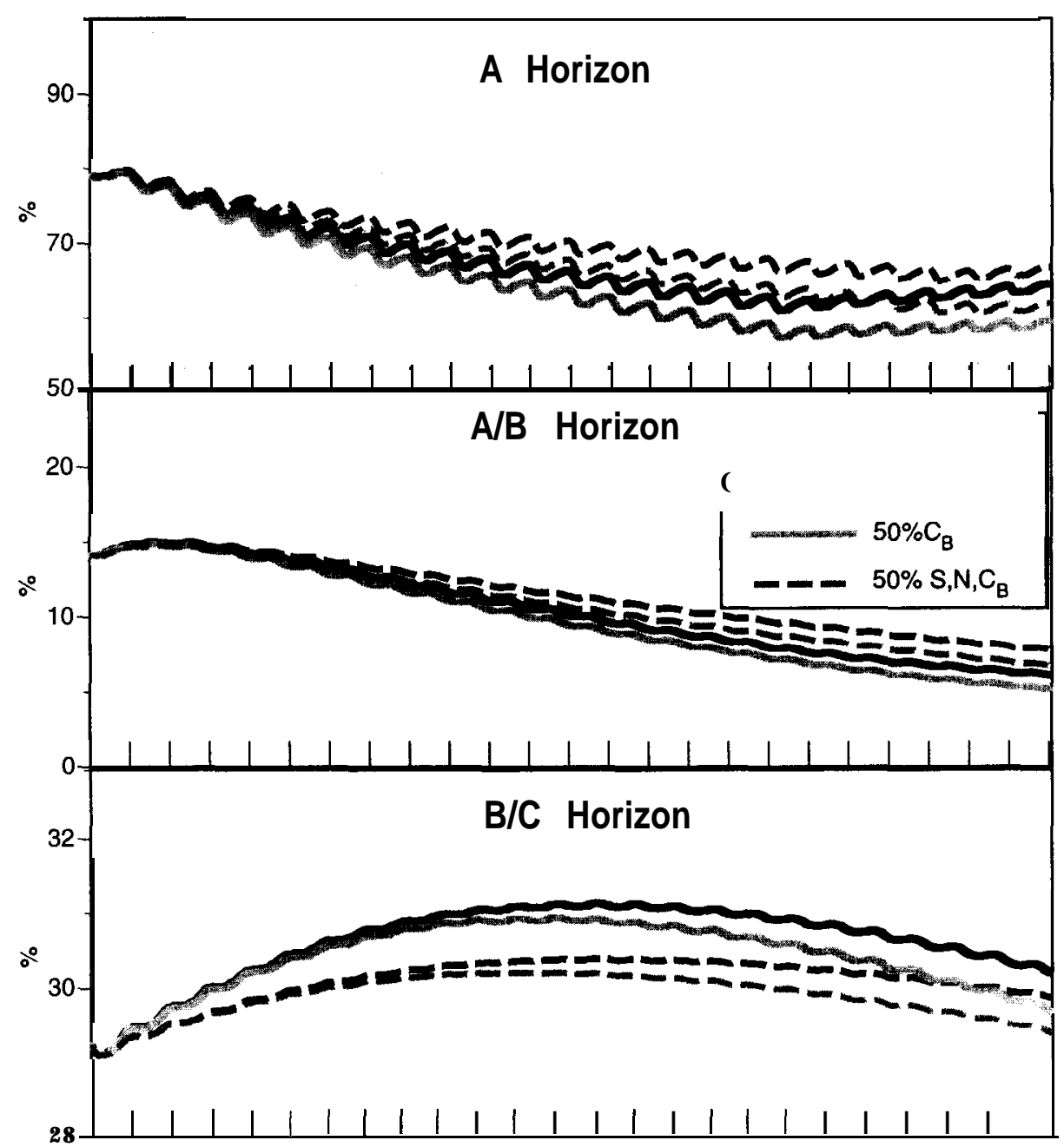

Fig. 7. Simulated soil solution $\mathrm{SO}_{4}^{2-}($ left $)$ and $\mathrm{NO}_{3}^{-}$(right) in the $\mathrm{BC}$ horizon at Coweeta (see Fig. 1 for key).

\section{E ffects on Simulated Base Cation Contents and Fluxes}

\section{Nolan Divide}

At the Nolan Divide site, the effects of the various scenarios on vegetation and forest floor $\mathrm{Ca}^{2+}, \mathrm{K}^{+}, \mathrm{Mg}^{2+}$, and $C_{\mathrm{B}}$ pools were small $(0-2 \%)$ relative to the No Change scenario, but effects on ecosystem fluxes and soil exchangeable pools were substantial (Table 1). The $50 \% \mathrm{~N}, \mathrm{~S}$ scenario caused reduced leaching and less negative (or more positive) ecosystem balances of $\mathrm{Ca}^{2+}$, $\mathrm{K}^{+}, \mathrm{Mg}^{2+}$, and $C_{\mathrm{B}}$. This in turn caused substantial (27$38 \%$ ) increases in soil exchangeable $\mathrm{Ca}^{2+}, \mathrm{K}^{+}, \mathrm{Mg}^{2+}$, and $C_{\mathrm{B}}$ pools. The $50 \% \quad C_{\mathrm{B}}$ scenario also caused reduced' leaching of $\mathrm{Ca}^{2+}, \mathrm{K}^{+}, \mathrm{Mg}^{2+}$, and $C_{\mathrm{B}}$; however, reduced $\mathrm{Ca}^{2+}, \mathrm{K}^{+}, \mathrm{Mg}^{2+}$, and $C_{\mathrm{B}}$ deposition in this scenario caused ecosystem balances to become more negative. This in turn caused substantial decreases ( -24 to $-29 \%)$ in soil exchangeable $\mathrm{Ca}^{2+}, \mathrm{K}^{+}, \mathrm{Mg}^{2+}$, and $C_{\mathrm{B}}$ pools. The $50 \% \mathrm{~N}, \mathrm{~S}, \boldsymbol{C}_{\mathrm{B}}$ scenario caused reduced leaching of all base cations and more negative ecosystem balances of all but $\mathrm{Mg}^{2+}$. The $50 \% \mathrm{~N}, \mathrm{~S}, C_{\mathrm{B}}$ scenario also caused reductions in soil exchangeable $\mathrm{Ca}^{2+}, \mathrm{K}^{+}$, $\mathrm{Mg}^{2+}$, and $C_{\mathrm{B}}$ pools $(-3$ to $-8 \%)$, but less than in the $50 \% C_{\mathrm{B}}$ scenario.

\section{Coweeta}

At Coweeta, the effects of the various scenarios on vegetation, forest floor, and soil exchangeable $\mathrm{Ca}^{2+}, \mathrm{K}^{+}$, $\mathrm{Mg}^{2+}$, and $C_{\mathrm{B}}$ pools were uniformly small ( -6 to $\left.+3 \%\right)$ (Table 2). The effects of the $50 \% \mathrm{~N}, \mathrm{~S}$, and $50 \% \mathrm{~N}, \mathrm{~S}$, $C_{\mathrm{B}}$ scenarios on vegetation $\mathrm{Ca}^{2+}, \mathrm{K}^{+}, \mathrm{Mg}^{2+}$, and $C_{\mathrm{B}}$ pools were larger than those at Nolan Divide, however, because the site was $\mathrm{N}$-limited and reducing $\mathrm{N}$ deposition caused reduced growth. The $50 \% \mathrm{~N}, \mathrm{~S}$, scenario caused reduced leaching and a more positive (or less negative) ecosystem balance of all base cations, as was the case at Nolan Divide. In contrast to Nolan Divide, however, the $50 \% C_{\mathrm{B}}$ scenario had no effect on $\mathrm{Ca}^{2+}$ or $\mathrm{K}^{+}$leaching and a very small effect on $\mathrm{Mg}^{2+}$ and $C_{\mathrm{B}}$ leaching. Thus, the reduced deposition in the $50 \% \quad C_{\mathrm{B}}$ scenario caused relatively large effects on ecosystem balances of $\mathrm{Ca}^{2+}, \mathrm{K}^{+}, \mathrm{Mg}^{2+}$, and $C_{\mathrm{B}}$ than the $50 \% \mathrm{~N}, \mathrm{~S}$ scenario did. 

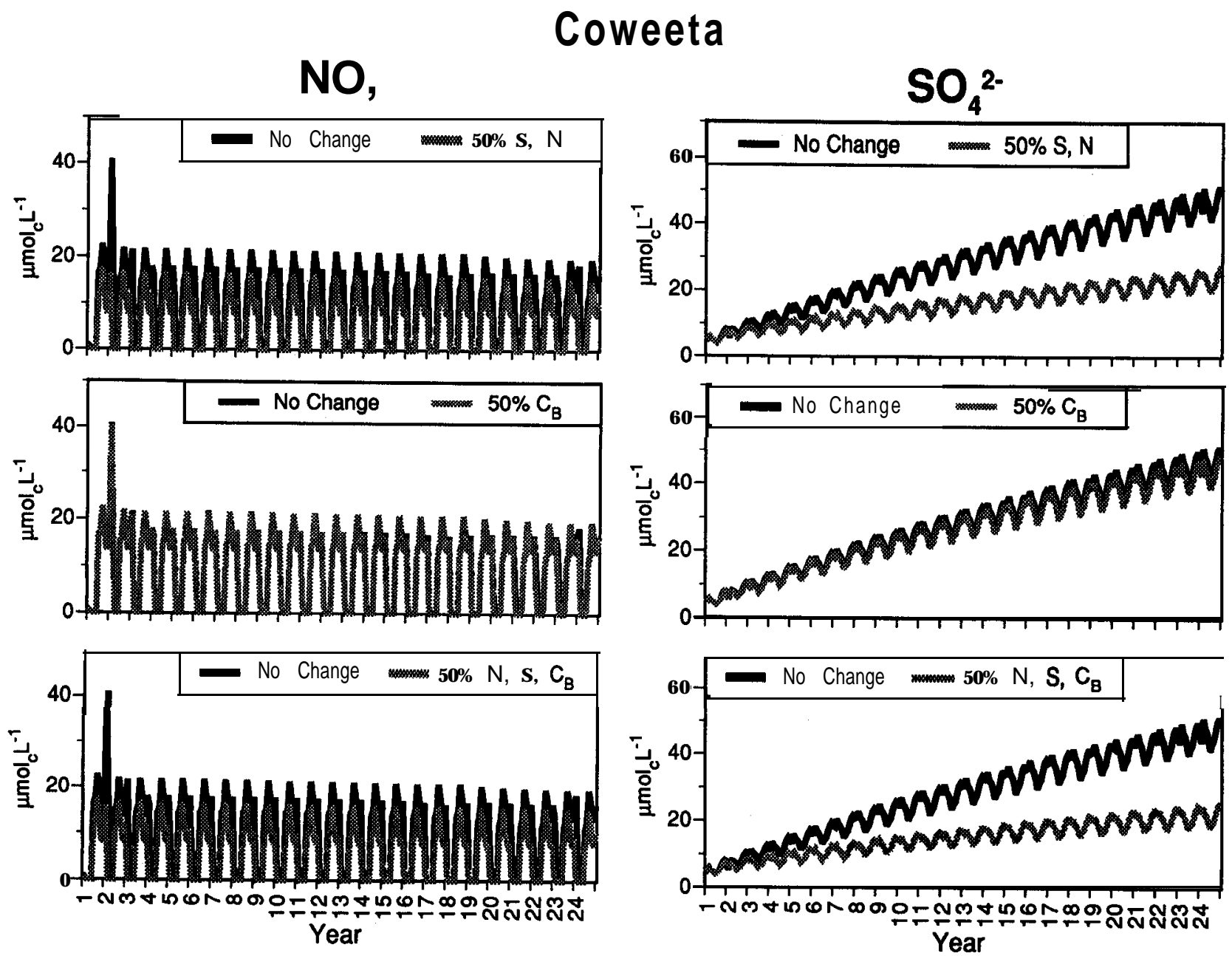

Fig. 8. Simulated base saturation at Coweeta (see Fig. 1 for key).

Because of their large size, however, soil exchangeable $\mathrm{Ca}^{2+}, \mathrm{K}^{+}, \mathrm{Mg}^{2+}$, and $C_{\mathrm{B}}$ pools were only slightly affected by the changes in ecosystem balances in the $50 \% C_{\mathrm{B}}$ scenario.

\section{DISCUSSION \\ Simulation Results from Nolan Divide and Coweeta}

The NuCM simulations suggest that, for the extremely acid Nolan Divide system, $\mathbf{S}$ and $\mathbf{N}$ deposition is the major factor affecting soil solution $\mathrm{Al}$ concentrations and $C_{\mathrm{B}}$ deposition is the major factor affecting soil solution $C_{\mathrm{B}}$ concentrations. The effects of $\mathrm{S}$ and $\mathrm{N}$ deposition were largely through changes in soil solution MAA concentrations rather than through changes in soils. On the other hand, the effects of $C_{\mathrm{B}}$ deposition were solely through changes in soils rather than through changes in soil solution MAA. The reversal in base saturation changes with depth in the $50 \% \mathrm{~N}, \mathrm{~S}$ scenario is a key factor in the responses observed; it is not known whether such patterns occur under field conditions or not.

In the less acid Coweeta soil, base saturation was high, $\mathrm{Al}$ was unimportant, and $\mathrm{S}$ and $\mathrm{N}$ deposition had a much greater effect than $C_{\mathrm{B}}$ deposition in all respects. As noted previously (Johnson et al., 1993), reducing $S$ deposition did not cause reduced soil solution $\mathrm{SO}_{4}^{2-}$ concentrations at Coweeta because of the high degree of soil $\mathrm{SO}_{4}^{2-}$ adsorption, even at $50 \% \mathrm{~S}$ deposition. Wesselink et al. (1995) described a similar but more complicated situation with reduced $\mathbf{S}$ deposition at the Solling, Germany, site over the period 1969 to 1991. During the 1970s, a strong acidification in both beech (Fagus sp.) and spruce soils was measured and attributed to increases in $\mathrm{SO}_{4}^{2-}$ leaching. After 1976, both atmospheric $\mathrm{S}$ deposition and $\mathrm{SO}_{4}^{2-}$ leaching began to decline; but the acidification of soils and solutions continued because of both $\mathrm{SO}_{4}^{2-}$ desorption and declines in $C_{\mathrm{B}}$ deposition. Wesselink et al. (1995) found that their model accounted for these soil changes and helped elucidate some of the underlying interactions that caused them.

\section{General Observations}

The NuCM model, like others of its kind (Goldstein et al., 1984; Cosby et al., 1985), was built on the premise that total cation leaching is driven by the input, production, and mobility of anions. Specifically, the anion mobility model holds that total cations must equal total 
Table 1. Simulated contents and budgets of base cations for the Nolan Divide site.

\begin{tabular}{|c|c|c|c|c|}
\hline & No change & $50 \%$ N.S & $50 \% \boldsymbol{C}_{\mathrm{B}}$ & $50 \% \mathrm{~N}, \mathrm{~S}, \boldsymbol{C}_{\mathrm{B}}$ \\
\hline & & $-\mathbf{k m}$ & ha-' & \\
\hline & & $\mathrm{Ca}$ & & \\
\hline \multicolumn{5}{|l|}{ Rluxes over $24 \mathrm{yr}$} \\
\hline Deposition & 20.0 & 20.0 & 10.0 & 10.0 \\
\hline Leaching & 19.9 & 18.5 & 11.3 & 10.5 \\
\hline Balance & 0.1 & 1.5 & -1.3 & -0.5 \\
\hline \multicolumn{5}{|c|}{ Contents at $Y$ ear 24} \\
\hline Vegetation & 21.0 & 20.9 & $2 Q .9$ & 20.8 \\
\hline Forest floor & 8.6 & 8.5 & 8.5 & 8.5 \\
\hline \multirow[t]{2}{*}{ Soil, exch. } & 4.2 & 5.8 & 3.0 & 3.8 \\
\hline & & $\underline{K}$ & & \\
\hline \multicolumn{5}{|l|}{ Fluxes over 24 yr } \\
\hline Deposition & 4.2 & 4.2 & 2.1 & 2.1 \\
\hline Leaching & 5.0 & $\mathbf{3 . 3}$ & 4.7 & 3.5 \\
\hline Balance & -0.8 & 0.9 & -2.6 & -1.4 \\
\hline \multicolumn{5}{|c|}{ Contents at $Y$ ear 24} \\
\hline Vegetation & 3.1 & 3.0 & 3.1 & 3.0 \\
\hline Forest floor & 6.2 & 6.2 & 6.2 & 6.2 \\
\hline Soil, exch. & 6.3 & 7.9 & 4.4 & 5.7 \\
\hline \multicolumn{5}{|c|}{$\underline{\mathbf{M g}}$} \\
\hline \multicolumn{5}{|l|}{ Fluxes over $24 \mathbf{y r}$} \\
\hline Deposition & 4.9 & 49 & 2.5 & 2.5 \\
\hline Leaching & 11.7 & 9.4 & 10.5 & 8.9 \\
\hline \multirow{2}{*}{\multicolumn{5}{|c|}{ Contents at Y ear $24^{-0.8}$}} \\
\hline & & & & \\
\hline Vegetation & 3.4 & 3.4 & 3.4 & 3.4 \\
\hline Forest floor & 1.7 & 1.7 & 1.7 & 17 \\
\hline Soil, exch. & 4.4 & 5.9 & 3.3 & 4.2 \\
\hline \multicolumn{5}{|c|}{$C_{B}$} \\
\hline \\
\hline & 37.3 & 37.3 & 18.6 & 18.6 \\
\hline Leading & 44.7 & 39.2 & 30.9 & 27.2 \\
\hline Balance & -7.5 & -1.9 & $\cdot 12.3$ & -8.6 \\
\hline \multicolumn{5}{|c|}{ Contents at $Y$ ear 24} \\
\hline Vegetation & 27.5 & 27.3 & 27.4 & 27.2 \\
\hline Forest floor & 16.5 & 16.4 & 16.4 & 16.4 \\
\hline soil, exch. & 14.8 & 19.6 & 10.7 & 13.7 \\
\hline
\end{tabular}

anions and therefore soil solution total concentration is controlled by the production and mobility of anions (Nye and Greenland, 1960; McColl and Cole, 1968; Johnson and Cole, 1980). These anions can be conceptually separated into two categories: (i) strong, or mineral acid anions (MAA; $\mathrm{SO}_{4}^{2-}, \mathrm{NO}_{3}^{-}, \mathrm{Cl}-$ ), which are only indirectly affected by soil solution $\mathrm{pH}$ (e.g., via adsorption); and (ii) weak acid anions (HCO;, ortho-phosphate, and organic anions) whose concentration is $\mathrm{pH}$ dependent. The composition of cations (but not total cation concentration) is then determined by cation exchange relationships.

The NuCM model cannot be used to test the validity of the anion mobility paradigm because it is built around this paradigm. However, the NuCM simulations on the Nolan Divide site clearly show that $C_{\mathrm{B}}$ deposition can have major effect on leaching within the context of the anion mobility paradigm via changes in the composition of the soil exchange complex. The NuCM simulations at the Coweeta site showed that $C_{\mathrm{B}}$ deposition can affect the level of anions by causing changes in base saturation, which in turn affect soil solution $\mathrm{pH}$ the degree of $\mathrm{SO}_{4}^{2-}$ adsorption. While this effect was very slight in this particular set of simulations, it could have been more pronounced in a more acidic soil with a high $\mathrm{SO}_{4}^{2-}$ adsorption capacity. Also, changes in base saturation and
Table 2. Simulated contents and budgets of base cations for the Coweeta site.

\begin{tabular}{|c|c|c|c|c|}
\hline & No change & $50 \% \mathrm{~N}, \mathrm{~S}$ & $50 \% C_{\mathrm{B}}$ & $50 \% \mathrm{~N}, \mathrm{~S}, C_{\mathrm{B}}$ \\
\hline & & - $\mathbf{k m o}$ & $\mathrm{ha}^{-1}$ & \\
\hline & & $\mathrm{Ca}$ & & \\
\hline \multicolumn{5}{|l|}{ Fluxes over $24 \mathrm{yr}$} \\
\hline Deposition & 9.1 & 9.1 & 4.5 & 4.5 \\
\hline Leaching & 1.5 & 1.0 & 1.5 & 1.0 \\
\hline Balance & 7.4 & 8.1 & 3.0 & 3.5 \\
\hline \multicolumn{5}{|c|}{ Contents at $Y$ ear 24} \\
\hline Vegetation & 22.0 & 20.8 & 22.0 & 20.8 \\
\hline \multirow[t]{2}{*}{$\begin{array}{l}\text { Forest floor } \\
\text { Soil, exch. }\end{array}$} & $\begin{array}{c}9.3 \\
63.5\end{array}$ & $\begin{array}{r}9.1 \\
65.4\end{array}$ & $\begin{array}{r}9.3 \\
59.0^{\circ}\end{array}$ & $\begin{array}{r}9.1 \\
60.9\end{array}$ \\
\hline & & $\mathrm{K}$ & & \\
\hline \multicolumn{5}{|l|}{ Fluxes over 24 yr } \\
\hline Deposition & 0.8 & 0.8 & 0.4 & OA \\
\hline Leaching & 1.5 & 1.3 & 1.5 & $\begin{array}{r}1.3 \\
-0.9\end{array}$ \\
\hline \multirow{2}{*}{ Contents at Y ear 24} & -0.7 & -0.5 & -1.1 & -0.9 \\
\hline & 24 & 3.9 & 4.1 & 3.9 \\
\hline \multirow{3}{*}{$\begin{array}{l}\text { Vegetation } \\
\text { Forest floor } \\
\text { Soil, exch. }\end{array}$} & 4.6 & 4.4 & 4.6 & 4.4 \\
\hline & 25.3 & 25.8 & 24.9 & 25.4 \\
\hline & & $\underline{\mathbf{M g}}$ & & \\
\hline \multicolumn{2}{|l|}{ Fluxes over $24 \mathrm{yr}$} & & 1.0 & \\
\hline Deposition & 2.1 & 2.1 & 8.9 & 1.0 \\
\hline Leaching & 8.7 & 7.2 & & $7 \mathrm{~A}$ \\
\hline Balance & -6.6 & -5.1 & -7.9 & -6.4 \\
\hline \multicolumn{5}{|c|}{ Contents at Y ear 24} \\
\hline Vegetation & 4.3 & 41 & & 4.1 \\
\hline Forest floor & 4.8 & 47 & 4,8 & 4.7 \\
\hline \multirow{2}{*}{ Soil, exch. } & 52.8 & 54.6 & 51.6 & $\mathbf{5 3 . 4}$ \\
\hline & & $\underline{C_{\mathrm{B}}}$ & & \\
\hline \multicolumn{5}{|l|}{ Fluxes over 24 yr } \\
\hline Deposition & 15.2 & 15.2 & 7.6 & 7.6 \\
\hline Leaching & 15.2 & 12.7 & 14.6 & 12.2 \\
\hline Balance & 0.0 & 2.5 & -7.0 & -4.6 \\
\hline \multicolumn{5}{|c|}{ Contents at Y ear 24} \\
\hline \multirow{3}{*}{$\begin{array}{l}\text { Vegetation } \\
\text { Forest floor } \\
\text { Soil, exch. }\end{array}$} & 31.3 & 29.7 & 31.3 & 29.7 \\
\hline & 19.1 & 18.6 & 19.0 & 18.6 \\
\hline & 143.7 & 148.2 & 136.8 & 141.3 \\
\hline
\end{tabular}

soil solution $\mathrm{pH}$ can certainly cause changes in soil solution $\mathrm{HCO}$; concentrations.

In the case of the controversy over the cause of the streamwater $C_{\mathrm{B}}$ decline at Hubbard Brook, an implicit question is being asked: do anions control cations or vice versa? One could argue, for example, that total anions must equal total cations and therefore take the opposite approach from the anion mobility paradigm: determine the factors affecting cation mobility and anions must follow. As noted earlier, changing $\mathrm{N}, \mathrm{S}$, and $C_{\mathrm{B}}$ deposition rates necessarily caused changes in $\mathrm{H}^{+}$deposition rates in the NuCM simulations. Hydrogen ion deposition was reduced by 81 and $79 \%$ in the $50 \% \mathrm{~N}, \mathrm{~S}$ scenarios, increased by 42 and $37 \%$ in the $50 \%$ $C_{\mathrm{B}}$ scenarios, and reduced by 49 and $31 \%$ in the $50 \%$ $\mathrm{N}, \mathrm{S}, C_{\mathrm{B}}$ scenarios at Nolan Divide and Coweeta, respectively. Thus, all effects attributed to the $50 \% \mathrm{~N}, \mathrm{~S}$ scenario could also be interpreted as the effects of the $-20 \% \mathrm{H}^{+}$scenario, those attributed to the $50 \% C_{\mathrm{B}}$ scenario could be interpreted as effects of the $-140 \% \mathrm{H}^{+}$ scenario, and those attributed to the $50 \% \mathrm{~N}, \mathrm{~S}, C_{\mathrm{B}}$ scenario interpreted as the $-40 \% \mathrm{H}^{+}$scenario. From this perspective, one could interpret the simulation results to indicate that $\mathrm{H}^{+}$deposition is the primary factor affecting soil exchangeable $\mathrm{Ca}^{2+}, \mathrm{K}^{+}, \mathrm{Mg}^{2+}$, and $C_{\mathrm{B}}$ pools, which followed the pattern $\left(-20 \% \mathrm{H}^{+}\right.$or $50 \%$ $\mathrm{N}, \mathrm{S}$ scenario $)>\left(-40 \% \mathrm{H}^{+}\right.$or $50 \% \quad C_{\mathrm{B}}$ scenario $)>$ 
(No Change) $>\left(-140 \% \mathrm{H}^{+}\right.$or $50 \% \mathrm{~N}, \mathrm{~S}, C_{\mathrm{B}}$ scenario $)$ in nearly all cases (the exception being $\mathrm{Mg}^{2+}$ at Coweeta; Tables 1 and 2). Hydrogen ion deposition alone does not begin to account for the patterns in leaching or soil solution concentrations, however; a far more complicated paradigm is needed.

In reality, either the anion or cation mobility paradigm is overly simplistic for real-world biogeochemical cycling systems. It impossible to evaluate the effects of $\mathrm{N}, \mathrm{S}, C_{\mathrm{B}}$, or $\mathrm{H}^{+}$deposition as single factors; interactions among ions come into play even before deposition strikes the forest canopy.

\section{CONCLUSIONS}

The results of the Nolan Divide simulations support the hypothesis of Driscoll et al. (1989a) in part: $C_{\mathrm{B}}$ deposition can have a major effect on $C_{\mathrm{B}}$ leaching through time in an extremely acid system. This effect occurred through changes in the soil exchanger and not through changes in soil solution MAA concentration. On the other hand, $\mathbf{S}$ and $\mathrm{N}$ deposition had a major effect on Al leaching at the Nolan Divide site. This occurred primarily because of changes in soil solution MAA concentration. At the less acidic Coweeta site, $C_{\mathrm{B}}$ deposition had a minor effect on soils and soil solutions whereas $\mathrm{S}$ and $\mathrm{N}$ deposition had delayed but major effects on $C_{\mathrm{B}}$ leaching because of changes in $\mathrm{SO}_{4}^{2-}$ and MAA concentration.

\section{ACKNOWLEDGMENTS}

Support was provided by the Tennessee Valley Authority under contract TV-94012V and by the Nevada Agricultural Experiment Station.

\section{REFERENCES}

Binkley, D., D. Valentine, C. Wells, and U. Valentine. 1989. An empirical model of the factors contributing to 20-year decrease in soil $\mathrm{pH}$ in an old-field plantation of loblolly pine. Biogeochemistry $8: 39-54$

Cosby, B.J., G.M. Hornberger, J.N. Galloway, and R.F. Wright. 1985. Modeling the effects of acid deposition: Assessment of a lumped parameter model of soil water and streamwater chemistry. Water Resour. Res. 21:51-63.

Cronan, C.S., and D.F. Grigal. 1995. Use of calcium/aluminum ratios as indicators of stress in forest ecosystems. J. Environ. Qual. 24: 209-226.

Driscoll, C.T., G.E. Likens, L.O. Hedin, and F.H. Bormann. 1989a. Letter to the editor. Environ. Sci. Technol. 23:1078.

Driscoll, C.T., G.E. Likens, L.O. Hedin, and F.H. Bormann. 1989b. Letter to the editor. Environ. Sci. Technol. 23:1079-1080.

Driscoll, C.T., G.E. Likens, L.O. Hedin, J.S. Eaton, and F.H. Bormann. 1989c. Changes in the chemistry of surface waters. Environ. Sci. Technol. 23:137-143.

Falkengren-Grerup, U., N. Linnermark, and G. Tyler. 1987. Changes in acidity and cation pools of south Swedish soils. Chemosphere $16: 10-12$.

Goldstein, R.A., S.A. Gherini, C.W. Chen, L. Mok, and R.J.M. Hudson. 1984. Integrated acidification study (ILWAS): A mechanistic ecosystem analysis. Phil. Trans. R. Soc. Lond. B 305:259-279.

Hedin, L.O., L. Granat, G.E. Likens, T.A. Buishand, J.N. Galloway, T.J. Butler, and H. Rodhe. 1994. Steep declines in atmospheric base cations in regions of Europe and North America. Nature (London) 367:351-354.

Holdren. G.R.. and H.R. Church. 1989. Letter to the editor. Environ. Sci. Tkchnoi. 23:1078-1079.

Johnson, A.H., and S.B. Andersen. 1994. Acid rain and soils of the Adirondacks: I. Changes in $\mathrm{pH}$ and available calcium, 1930-1984. Can J. For. Res. 24:39-45.

Johnson, D.W., and D.W. Cole. 1980. Anion mobility in soils: Relevance to nutrient transport from terrestrial ecosystems. Environ. Int. 3:79-90.

Johnson, D.W., G.S. Henderson, and D.E. Todd. 1988. Changes in nutrient distribution in forests and soils of Walker Branch Watershed over an eleven-year period. Biogeochemistry 5:275-293.

Johnson, D.W., and S.E. Lindberg (ed.). 1991. Atmospheric deposition and forest nutrient cycling. Ecological Series 91. Springer-Verlag, New York.

Johnson, D.W., R.B. Susfalk, and P.F. Brewer. 1996. Simulated responses of red spruce forest soils to reduced sulfur and nitrogen deposition. J. Environ. Qual. 25:1300-1309.

Johnson. D.W.. W.T. Swank. and J.M. Vose. 1993. Simulated effects of atmospheric sulfur deposition on nutrient cycling in a mixed deciduous forest. Biogeochemistry 23:169-196.

Johnson, D.W., H. Van Miegroet, S.E. Lindberg, R.B. Harrison, and D.E. Todd. 1991. Nutrient cycling in red spruce forests of the Great Smoky Mountains. Can. J. For. Res. 21:769-787.

Joslin. J.D.. J.M. Kellv, and H. Van Miearoet. 1992. Soil chemistry and nutrition of North American spruce-fir stands: Evidence for recent changes. J. Environ. Qual. 21:12-30.

Liu, S., R. Munson, D. Johnson, S. Gherini, K. Summers, R. Hudson, K. Wilkinson, and L. Pitelka. 1991. Application of a nutrient cycling model $(\mathrm{NuCM})$ to northern mixed hardwood and southern coniferous forest. Tree Physiol. 9:173-182.

Likens, G.E., C.T. Driscoll, and D.C. Buso. 1996. Long-term effects of acid rain: Reponse and recovery of a forest ecosystem. Science (Washington, DC) 272:244-246.

Lynch., J.A.., J.W. Grimm. and V.C. Bowersox. 1995. Trends in me\&itation chemistry in the United States: A national perspective, 19801992. Atmos. Environ. 29:1231-1246.

McColl, J.G., and D.W. Cole. 1968. A mechanism of cation transport in a forest soil. Northwest Sci. 42:132-140.

Munsen, R.K., S. Liu, S.A. Gherini, D.W. Johnson, K.J. Wilkinson, R.J.M. Hudson, K.S. White, and K.V. Summers. 1992. NuCM Code Version 2.0: An IBM PC code for simulating nutrient cycling in forest ecosystems. Tetra-Tech, Hadley, MA.

Nye, P.H., and D.J. Greenland. 1960. The soil under shifting cultivation Commonwealth Bureau of Soils. Tech. Commun. 51. Farnham Royal, Commonwealth Agricultural Bureaux, Bucks, UK.

Prenzel, J. 1994. Sulfate sorption in soils under acidic deposition: Comparison of two modeling approaches. J. Environ. Qual. 23: 188-194.

Swank, W.T., and J.B. Waide. 1988. Characterization of baseline precipitation and stream chemistry and nutrient budgets for control watersheds. p. 57-79. In W.T. Swank and D.A. Crossley (ed.) Forest hydrology and ecology of Coweeta. Springer-Verlag, New York.

Wesselink, L.G., K.-J. Meiwes, E. Matzner, and A. Stein. 1995. Longterm changes in soil chemistry in spruce and beech forests, Solling, Germany. Environ. Sci. Technol. 29:51-58. 